\title{
Pendekatan Sejarah Penebusan dalam Penafsiran Alkitab
}

\author{
The Redemptive-Historical Approach in Bible Interpretation
}

\begin{tabular}{l} 
Author: \\
Made Nopen Supriadi \\
Affiliation: \\
Sekolah Tinggi Teologi \\
Arastamar Bengkulu \\
madenopensupriadi@sttab.ac \\
\hline .id \\
Dates: \\
Submitted: \\
13 February 2021 \\
Accepted: \\
7 May 2021 \\
Published: \\
17 May 2021 \\
\\
DOI: \\
$10.46494 / p s c . v 17 i 1.136$
\end{tabular}

\section{Copyright:}

(C) 2021. The Authors. Licensee: Licensee: PASCA. This work is licensed under the Creative Commons Attribution-ShareAlike 4.0 International License.

\begin{abstract}
The substance of the Bible verse can be understood by analyzing it until it finds the eternal and universal principle of a verse. The interpretation of Bible verses is only on finding the meaning of the past and present context, causing problems in terms of substance. Through a descriptive study, this paper explains a principle of biblical interpretation using a redemptive historical approach. The results of this study explain that there are many Bible verses that have a continuous meaning in the present and future context, and there is a change in form in the relevance of these verses. So that, through the historical redemptive approach, the interpreters can find the substance of the Bible verses that will be able to be universally and eternally relevant.

[Substansi ayat Alkitab dapat dipahami dengan melakukan analisis sampai menemukan prinsip kekal dan universal dari sebuah ayat. Penafsiran ayat Alkitab hanya pada menemukan arti konteks lampau dan masa kini, menimbulkan problematika dalam hal substansi. Melalui kajian deskriptif tulisan ini menjelaskan sebuah prinsip penafsiran Alkitab dengan metode pendekatan sejarah penebusan. Hasil penelitian ini menjelaskan bahwa ada banyak ayat Alkitab yang memiliki makna berkelanjutan dalam konteks masa kini dan masa yang akan datang, serta adanya perubahan bentuk dalam relevansi ayat-ayat tersebut. Sehingga melalui metode pendekatan sejarah penebusan para penafsir dapat menemukan substansi ayat Alkitab yang akan mampu direlevansikan secara universal dan kekal.]

Research Contribution: This research strengthens the doctrinal understanding of the history of redemption (theological contribution). It maintains consistency in the preaching of Christ's work in every reading and interpretation of the Bible for missiological purposes. The use of its application for curriculum development in systematic theology and hermeneutical science.
\end{abstract}

Keywords: implementation, redemptive, historical, bible approach, interpretation.

\section{Pendahuluan}

tudi Alkitab merupakan bagian penting dalam konteks masa kini. Studi tersebut membutuhkan pembelajaran yang komprehensif agar memahami konteks Alkitab, sastra atau budaya, penguasaan bahasa asli Alkitab (Ibrani, Aram dan Yunani) dan penguasaan prinsip-prinsip doktrinal. Mengenai hal tersebut Agus Marjanto menuliskan bahwa perlunya mengetahui 4 pilar utama dalam mengerti makna Kitab Suci. Pertama, fakta bahwa Alkitab hanya memiliki satu pengarang agung. 
Kedua, fakta bahwa Kristus hadir dalam Perjanjian Lama. Ketiga, fakta bahwa Kristus itu pusat dari Alkitab. Keempat, fakta bahwa doktrin-doktrin dalam Alkitab dihubungkan bersama antar teks dan kecenderungan untuk dapat membangun satu doktrin di atas doktrin lainnya. ${ }^{1}$ Namun dalam penafsiran Alkitab masih ada problematika dalam memahami makna dan relevansi teks Alkitab. Kesulitan dalam memahami makna dan relevansi teks Alkitab dikarenakan penafsir terjebak dalam konteks masa lampau dan masa kini.

Stenly J. Grenz menuliskan tantangan pemikiran zaman postmodern menolak kebenaran obyektif dan universal.² Pandangan tersebut memberikan pengaruh kepada para pembaca postmodern menolak sistem yang sudah baku bahkan pengajaran atau doktrin yang sudah baku.3 Dengan demikian postmodern menjadi tantangan para penafsir Alkitab masa kini, untuk menafsirkan teks Alkitab agar tetap obyektif, koheren dan berdasarkan kebenaran yang telah diakui secara absolut dalam iman Kristen. ${ }^{4}$ Penafsir mengalami kesulitan ketika ingin menyampaikan konteks dan kata asli Alkitab, karena penyampaian tersebut bukan hal yang penting bagi pendengar. Para pendengar Alkitab hanya ingin mengetahui makna dari

\footnotetext{
${ }^{1}$ Billy Kristanto, ed., "Metode Bertheologi Reformed," in Aspek-Aspek Dalam Pemikiran John Calvin (Surabaya: Momentum, 2012), 20-21.

${ }^{2}$ Stenly J Grenz, A Primer On Postmodenism

(Yogyakarta: ANDI, 2001), 68-69.

3 Ramly B. Lumintang, Bahaya Postmodernism Dan Peranan Kredo Reformed (Batu: PPII, 2010), 163.

4 Made Nopen Supriadi, "Tinjauan Teologis Terhadap Postmodernisme Dan Implikasinya Bagi Iman Kristen," Manna Rafflesia, 2020,

https://doi.org/10.38091/man_raf.v6i2.115.

5 Sonny Eli Zaluchu, "Persoalan Corpus Delicti Dalam Teologi Kristen Tentang Persidangan Ilahi," KURIOS (Jurnal Teologi Dan Pendidikan Agama Kristen) 6, no. 2 (2020): 214-26,

https://doi.org/https://doi.org/10.30995/kur.v6i2.172. 6 Philip C Johnson, "Keluaran," in The Wyclife Bible Commentary, 1st ed., vol. 1 (Malang: Gandum Mas, 2011), 204.
}

sebuah ayat Alkitab sesuai atau tidak dengan konteks mereka. Kondisi demikian menciptakan kehidupan orang Kristen yang tidak lagi peduli terhadap kebenaran absolut yang telah dinyatakan Alkitab. Problematika tersebut membutuhkan jawaban bagaimana menyajikan penafsiran Alkitab yang cepat, tepat dan bertanggungjawab.

Pada masa kini masih ada problematika kegagalan dalam menentukan metode dan tema utama dalam menafsirkan Alkitab, yang berakibat hadirnya pandangan yang bertentangan dengan doktrin-doktrin Alkitab yang telah diakui. Hal tersebut dapat terlihat dalam tulisan Sonny Eli Zaluchu yang membahas tentang persoalan corpus delicti dalam prinsip pendekatan Erastus Sabdono dalam menafsirkan tentang penghukuman Lucifer yang bertentangan dengan prinsip Alkitab.5 Selanjutnya problematika penafsiran secara khusus dalam hal etika, salah satunya pengajaran yang menyangkut hukum Taurat. Penulis mengamati beberapa bentuk penafsiran dari Philip C. Johnson, 6 Budi Asali,7 Christie Kusnandar, ${ }^{8}$ Imanuel Zai dan Thuan Ong9 serta Queency Christie Wauran ${ }^{10}$ dalam menafsirkan hukum Taurat yang belum memfokuskan pada relevansi makna di masa yang akan datang. Penulis mengidentifikasi hal tersebut terjadi

\footnotetext{
7 Budi Asali, "10 Hukum Tuhan: Hukum Kedelapan," Golgotha Ministry, accessed February 27, 2021, http://www.golgothaministry.org/artikel/pengajaran_1 ohukumo8.htm.

${ }^{8}$ Christie Kusnandar, "Sepuluh Perintah Tuhan Bagian Kedua: Kasih Terhadap Manusia Dalam Tinjauan Etika Kristen," Jurnal Ilmiah Methonomi 3, no. 2 (2017): 7382.

9 Thuan Ong and Imanuel Zai, "Memahami Konsep Penebusan Dalam Hukum Taurat Dan Penggenapannya Dalam Diri Yesus Kristus," Jurnal Teologi Pondok Daud 6, no. 1 (2020): 1-7.

${ }_{10}$ Queency Christie Wauran, "Kajian Biblika

Kecemburuan Allah Terhadap Penyembahan Berhala Berdasarkan Keluaran 20:4-6," Jurnal Jaffray 13, no. 2 (February 13, 2015): 249, https://doi.org/http://dx.doi.org/10.25278/jj71.v13i2.18 o.
} 
karena penafsir tidak menerapkan metode penafsiran dengan berfokus pada sebuah benang merah yang mengikat setiap teks Alkitab baik dalam konteks pembaca awal maupun konteks kekekalan. Philip Suciadi Cia dan Juanda menuliskan tentang problematika memahami ayat Alkitab terjadi juga dalam konteks penafsiran yang telah menerapkan sebuah sistem benang merah, namun terlalu menekankan kehurufiahan teks sehingga menjadikan Alkitab hanya sebagai susunan ayat hanya untuk mendukung sebuah konsep yang salah, dan kesalahan garis besar tersebut diterapkan untuk menafsirkan teks-teks yang maknanya tidak bisa hanya secara harafiah.11 Penulis mengidetifikasi kesalahan tersebut karena tidak menerapkan horizon heremeneutika dengan tepat. Problematika tersebut banyak menimbulkan diskusi dan perdebatan dalam konteks penafsiran Alkitab.

Perdebatan dalam penafsiran teks banyak terjadi oleh karena pendekatan atau metode yang berbeda dalam memahami teks. Metode yang digunakan akan mempengaruhi hasil dari penafsiran, sehingga relevansi teks juga dipahami sesuai dengan metode yang digunakan. VanGemerem menuliskan banyak penafsir Alkitab merasa cukup dengan kehadiran Roh Kudus dalam menafsirkan Alkitab. Selanjutnya kehadiran Roh bukanlah dalih bagi tidak mempelajari Alkitab dengan tekun. Terlalu sering orang yang mempelajari Alkitab membuka Firman Tuhan hanya untuk mencari jawab bagi masalah yang di depan mata. ${ }^{12}$ Analisis sebuah teks Alkitab dengan memahami makna pada saat konteks Alkitab

\footnotetext{
${ }^{11}$ Philip Suciadi Chia and Juanda Juanda,

"Dispensasionalisme Sebagai Metode Dalam

Memahami Alkitab," Jurnal Teologi \& Pelayanan

KERUSSO 5, no. 1 (2020): 20-37.

12 Willem VanGemeren, Progress Penebusan: Kisah

Keselamatan Dari Penciptaan Sampai Yerusalem Baru

(Surabaya: Momentum, 2016), 14.

13 Misray Tunliu, "Eksistensi Kanon Alkitab Dan

Relevansinya Di Era Globalisasi," PRUDENTIA: Jurnal
}

dituliskan merupakan prinsip penting, namun problematika terjadi ketika makna teks perlu diterapkan pada konteks yang berbeda. Oleh karena itu perlu metode yang mampu menjelaskan makan sebuah teks secara luas dan mendetail dan dalam. Hal tersebut dapat dilakukan jika penafsir memahami sebuah teks dalam konteks masa yang akan datang.

Problematika penelitian ini didasarkan pada pemaknaan teks Alkitab. Makna sebuah teks yang mampu dipahami hingga konsep kekekalan akan memberikan dasar yang kuat bagi orang percaya untuk merelevansikan teks Alkitab. Namun jika makna Alkitab dipahami secara kontekstual atau hanya pada konteks masa lalu dan masa kini tanpa mendapatkan makna pada masa yang akan datang, maka akan memberikan kesulitan bagi pembaca Alkitab untuk bisa menyakini apakah teks tersebut masih perlu dilakukan. ${ }^{13}$ Secara etis, penafsiran Alkitab yang terbatas pada konteks tertentu baik makna masa lalu dan masa kini akan memberikan kesulitan dalam membangun keyakinan terhadap sebuah makna teks. Maka memahami teks Alkitab dalam konteks yang akan datang adalah kebutuhan yang sangat penting. Penelitian ini juga didasarkan pada penelitian sebelumnya yang telah menerapkan prinsip penafsiran Alkitab dengan menetapkan sebuah prinsip teologi, Cia dan Juanda menjelaskan tentang teologi perjanjian dalam memahami keseluruhan Kitab Suci, yang menjelaskan bahwa dalam pemikiran teologis tentang perjanjian juga melibatkan konsep perjanjian kerja, perjanjian penebusan dan perjanjian anugerah. ${ }^{14}$ Menanggapi hal tersebut

Teologi Dan Pendidikan Kristiani 1, no. 2 (2018): 14863.

14 Philip Suciadi Chia and Juanda Juanda, "Penafsiran Amilenialisme \& Teologi Kovenan Dalam Memahami Alkitab," Journal KERUSSO 5, no. 2 (February 27, 2020): 1-23, https://doi.org/10.33856/kerusso.v5i2.125. 
Zaluchu menuliskan bukunya Biblical

Theology menyatakan bahwa apapun metodologi yang digunakan, tujuannya ialah menemukan tema sentral yang mempersatukan antara Perjanjian Lama dan Perjanjian Baru dan menelusuri tema-tema dalam berbagai tahapan periode dan penulis Alkitab. ${ }^{15}$ Dengan demikian metode penafsiran Alkitab dengan memusatkan pada sebuah perspektif teologi telah diterima dan diakui dalam prinsip hermeneutika.

Penulis melihat satu prinsip doktrinal tentang sejarah penebusan yang dituliskan oleh Willem VanGemeren, prinsip sejarah penebusan menyatakan bahwa puncak dari penebusan adalah ketika terjadinya penyempurnaan (konsumasi) yaitu kehidupan manusia di langit dan di bumi yang baru. ${ }^{16}$ Prinsip doktrinal tersebut penulis amati menolong para pembaca Alkitab untuk menerangkan banyak teks Alkitab dengan relevansi yang sampai pada konteks kekekalan. Penelitian ini penulis lakukan sebelumnya dengan melakukan analisis beberapa teks dalam Perjanjian Lama dalam Keluaran 20: 12, $15^{17}$ dengan perspektif pendekatan sejarah penebusan. Dari hasil penelitian tersebut penulis menemukan esensi makna dan relevansi yang bernilai kekekalan terhadap sebuah perintah dalam Alkitab. Oleh karena itu berdasarkan hasil penelitian tersebut penulis mencoba untuk melakukan perumusan pola dan prinsip penafsiran dengan metode pendekatan sejarah penebusan.

\section{Metode}

Metode penelitian ini merupakan metode kualitatif deskriptif analisis. Penelitian ini menerapkan metode analisis deskriptif yang memberikan penjelasan terhadap bagianbagian penelitian, baik itu latar belakang, metode, pembahasan dan kesimpulan. ${ }^{18}$ Berikut adalah langkah-langkah penelitian, pertama, pemamparan tentang problematika dalam penafsiran Alkitab dan signifikansinya doktrin sejarah penebusan dalam menjawab persoalan. Kedua, dalam pembahasan penulis menjelaskan tentang doktrin sejarah penebusan dan perlunya doktrin tersebut menjadi sebuah metode untuk menafsirkan ayat-ayat Alkitab. Ketiga, penulis memberikan beberapa teks Alkitab yang perlu ditafsirkan dengan metode pendekatan sejarah penebusan. Keempat, penulis memberikan jawaban mengapa metode sejarah penebusan signifikan digunakan pada penafsiran Alkitab dan menunjukkan kebaharuan tentang prinsip penafsiran dengan metode sejarah penebusan. Pada bagian akhir penelitian ini penulis akan memberikan kesimpulan dan saran secara khusus perlunya menetapkan dan memutakhirkan sebuah prinsip penafsiran terhadap Alkitab, penulis menunjukkan kebaharuan penerapan metode sejarah penebusan dalam menghadapi konteks pembaca dan pendengar di era postmodern yang mengabaikan keabsolutan dan universalitas kebenaran Alkitab dan memegang prinsip multisentral.19 Penyelesaian penelitian ini juga menggunakan dukungan sumber pustaka yaitu artikel Jurnal yang relevan sesuai dengan judul penelitian dan topik yang dibahas

no. 2 (2020): 213-34,

https://doi.org/https://doi.org/10.47304/jl.v6i2.43.

${ }^{18}$ Sonny Eli Zaluchu, "Metode Penelitian Di Dalam

Manuskrip Jurnal Ilmiah Keagamaan," Jurnal Teologi

Berita Hidup 3, no. 2 (March 25, 2021): 249-66,

https://doi.org/10.38189/jtbh.v3i2.93.

19 H W B Sumakul, Postmodernitas: Memaknai

Masyarakat Plural Abad Ke - 21 (Jakarta: BPK Gunung Mulia, 2012)95-96. 
serta beberapa buku penting yang bersifat referensi dan mewakili pemikiran utama dalam pembahasan tulisan ini.

\section{Pembahasan}

Jhon Calvin (1509-1564 M) menuliskan bahwa metode berteologi bukanlah berarti membuat Alkitab melayani doktrin, artinya membaca dan menafsirkan Alkitab lalu mengatur logikalogika untuk melindungi, memperkuat, dan membela doktrin, sebaliknya metode berteologi yang benar adalah menyampaikan pesan yang terkandung di dalam Alkitab, penafsir menyatakan apa yang dituliskan Alkitab dan diam ketika Alkitab diam dan taat ketika Alkitab menyatakan.20 Mengenai hal tersebut Alkitab menyatakan bahwa pribadi dan karya Yesus Kristus adalah pusat pemberitaan Alkitab, Yesus Kristus yang telah berinkarnasi dan dipermuliakan, melalui Yesus segala sesuatu diciptakan dan diperbaharui. ${ }^{21}$ Segala tindakan Allah, penyataan tentang janji, kerajaan-Nya dan segala berkat keselamatan ada di dalam Yesus Kristus. Hal tersebut menjadi fokus dalam tulisan Oscar Cullman yang berjudul Christ and Time (1945) dan Salvation in History (1965), Eric C. Rust yang berjudul Salvation History (1962) dan Isaac C. Rottenberg yang berjudul Redemption and Historical Reality (1964)..22 Van Gemerem dalam tulisannya menyatakan bahwa pusat teologis Kitab Suci yang dapat memiliki fungsi sebagai prinsip-prinsip yang dapat melakukan pendekatan terhadap banyak penyataan biblikal adalah pemikiran tentang 'janji' dan 'kerajaan' yang kedua tema tersebut berpusat kepada Yesus Kristus, sehingga Yesus Kristus

\footnotetext{
${ }^{20}$ Henry Meeter, The Basic Idea of Calvinism, vol. 6 (Grand Rapids: Baker Academic, 1990), 28.

${ }^{21}$ VanGemeren, Progress Penebusan: Kisah Keselamatan Dari Penciptaan Sampai Yerusalem Baru, 12.

22 Yung Hoon Hyun, Redemptive-Historical Hermeneutics and Homiletics: Debates in Holland,
}

dapat dinyatakan sebagai penyataan keselamatan Allah. ${ }^{23}$

Secara garis besar VanGemerem menuliskan periode sejarah sejarah penebusan yang progresif dan akan dinyatakan secara lengkap atau sempurna dalam pemulihan segala sesuatu. ${ }^{24}$ Ungkapan Alkitab tentang berkat, janji, kovenan dan kerajaan adalah refleksi dari keselamatan di dalam Yesus Kristus yang sempurna di akhir zaman. Berdasarkan tabel tersebut memperlihatkan bahwa Perjanjian Lama dan Perjanjian Baru memberikan kesaksian yang sama tentang keselamatan yang puncak penggenapannya pada paraousia. Meskipun semua karya Allah Tritunggal didasarkan pada pribadi dan karya Yesus Kristus, namun manusia tidak dapat memastikan kondisi di zaman yang akan datang, sehingga banyak gambaran tentang puncak sejarah penebusan diberikan dengan metafora dan perumpamaan. Prinsip doktrinal sejarah penebusan yaitu bersifat Kristologis dan Eskatologis.25 Prinsip tersebut menunjukkan bahwa Yesus Kristus telah menggenapkan karya penebusan di kayu Salib namun realisasi karya penebusan bagi umat yang telah dipilih akan tergenapi pada masa yang akan datang, seluruh prinsip Alkitab akan direalisasikan pada masa yang akan datang dengan sempurna.

America, and Korea from 1930 to 2012 (Wipf and Stock Publishers, 2015), xx.

23 VanGemeren, Progress Penebusan: Kisah

Keselamatan Dari Penciptaan Sampai Yerusalem Baru, 11.

24 VanGemeren.

25 VanGemeren, 12. 
Bapa-bapa gereja yaitu Irenaeus $(130$ - $202 \mathrm{M})$ dari Lyon dan Anthanasius (296 - 373 M) dari Alexandria menanggapi ajaran Arianisme dengan membaca Alkitab dengan prinsip sejarah penebusan. ${ }^{26}$ Pendekatan sejarah penebusan berkembang pada masa reformasi gereja, Geerhardus Vos (1862 - 1949 M) pada waktu mengajar di Pricenton Theological Seminary, Amerika Serikat pada tahun 1893 1932 menekankan pentingnya peran sejarah

Table 1: Dua Belas Periode Sejarah Penebusan

\begin{tabular}{|c|c|c|c|}
\hline Awal (+) & Periode & $\begin{array}{l}\text { Kitab } \\
\text { Suci }\end{array}$ & Tema-Tema \\
\hline- & $\begin{array}{l}\text { Ciptaan dalam } \\
\text { Harmoni }\end{array}$ & Kej. 1-2 & $\begin{array}{l}\text { Yahweh adalah Raja Pencipta: manusia adalah wali-raja } \\
\text { dari Sang Raja Agung; kovenen dengan penciptaan. }\end{array}$ \\
\hline- & $\begin{array}{l}\text { Ciptaan dalam } \\
\text { keterasingan }\end{array}$ & Kej. 3-11 & $\begin{array}{l}\text { Pemberontakkan melawan kedudukan Allah sebagai } \\
\text { Raja; status keterasingan, dua kerajaan: kerajaan Allah } \\
\text { dan kerajaan manusia; kovenan Nuh }\end{array}$ \\
\hline $2000 \mathbf{s M}$ & $\begin{array}{l}\text { Pemilihan dan } \\
\text { janji }\end{array}$ & Kej. 12-50 & Janji, Kovenan Abraham dan Iman \\
\hline $1400 \mathrm{sM}$ & $\begin{array}{l}\text { Bangsa yang } \\
\text { Kudus }\end{array}$ & Kel. - Yos. & $\begin{array}{l}\text { Pemurnian Israel, kovenan Musa, kehadiran Yahweh; } \\
\text { kebutuhan akan raja manusia di Israel }\end{array}$ \\
\hline $1200 \mathrm{sM}$ & $\begin{array}{l}\text { Suatu Bangsa } \\
\text { Seperti } \\
\text { bangsa- } \\
\text { bangsa lain }\end{array}$ & $\begin{array}{lrr}\text { Hak. } & 1 & - \\
\text { 1Sam. } 15\end{array}$ & $\begin{array}{l}\text { Pemberontakkan Israel dan kedaulatan Yahweh; } \\
\text { kebutuhan akan raja manusia di Israel }\end{array}$ \\
\hline $1000 \mathrm{sM}$ & $\begin{array}{l}\text { Bangsa yang } \\
\text { Rajani }\end{array}$ & $\begin{array}{l}\text { 1Sam. } 16- \\
\text { 1Raj. } 11, \\
\text { 1Taw. } 1 \quad- \\
\text { 2Taw. } 9\end{array}$ & $\begin{array}{l}\text { Kovenan Daud, kemuliaan komunitas theokratis, dan } \\
\text { kehadiran Yahweh di bait Allah }\end{array}$ \\
\hline $931 \mathrm{sM}$ & $\begin{array}{l}\text { Bangsa yang } \\
\text { terbelah }\end{array}$ & $\begin{array}{l}\text { 1Raj. } 12- \\
\text { 2Raj. } 25, \\
\text { 2Taw. } 10- \\
36\end{array}$ & $\begin{array}{l}\text { Pemberontakkan Israel dan kebimbingan Yehuda; } \\
\text { kegagalan dinasti Daud; berita nubuat; sisa umat, hari } \\
\text { TUHAN, pembuangan dan pemulihan }\end{array}$ \\
\hline $538 \mathrm{sM}$ & $\begin{array}{l}\text { Bangsa yang } \\
\text { dipulihkan }\end{array}$ & $\begin{array}{l}\text { Ezr, Neh, } \\
\text { Nabi-nabi }\end{array}$ & Pemulihan: pembaharuan kovenan-kovenan \\
\hline $4 \mathrm{sM}$ & $\begin{array}{l}\text { Yesus dan } \\
\text { Kerajaan }\end{array}$ & Injil & $\begin{array}{l}\text { Pemberitaan Yesus, mujizat-mujizat, kematian, dan } \\
\text { kebangkitan: kehadiran kerajaan yang mulia di dalam } \\
\text { Anak, pembaharuan kovenan-kovenan, umat baru milik } \\
\text { Allah, persiapan akan kedatangan kembali Yesus di } \\
\text { dalam kemuliaan }\end{array}$ \\
\hline $29 \mathrm{M}$ & $\begin{array}{ll}\text { Era } & \text { Rasul- } \\
\text { Rasul } & \end{array}$ & $\begin{array}{l}\text { KPR dan } \\
\text { Surat-surat } \\
\text { PB }\end{array}$ & $\begin{array}{l}\text { Pemerintahan Yesus, kehadiran-Nya dalam Roh, } \\
\text { kemajuan gereja, transmisi tradisi apostolik: tulisan- } \\
\text { tulisan Perjanjian Baru }\end{array}$ \\
\hline $100 \mathrm{M}$ & $\begin{array}{l}\text { Kerajaan dan } \\
\text { Gereja }\end{array}$ & - & $\begin{array}{l}\text { Progresi gereja: tantangan menjadi umat Rajani dan } \\
\text { kudus di dunia }\end{array}$ \\
\hline- & $\begin{array}{l}\text { Yerusalem } \\
\text { Baru }\end{array}$ & $\begin{array}{l}\text { Kej. 3: } 1- \\
\text { Why. 22: } 21\end{array}$ & $\begin{array}{l}\text { Transformasi dan pemulihan: langit dan bumi baru; } \\
\text { penebusan ciptaan; umat yang kudus; kehadiran dan } \\
\text { pemerintahan yang penuh rahmat dari Allah dan Mesias- } \\
\text { Nya. }\end{array}$ \\
\hline
\end{tabular}

Sumber: Van GeMerem, Progress Penebusan, Surabaya: Momentum,2016, 20

${ }^{26}$ Michael Horton, Covenant and Eschatology: The Divine Drama (Louisville: Wesrminster John Knox, 2002), 5 . 
penebusan dalam penafsiran Alkitab sebagai kontra reaksi terhadap tradisi studi biblika protestan yang telah dipengaruhi oleh rasionalisme. Vos menuliskan bahwa Allah merangkaikan wahyu-Nya tidak dalam buku sistem dogmatik, namun dalam kisah sejarah penebusan agar hati manusia memahami dan tersentuh akan karya Allah yang nyata dalam sejarah. ${ }^{27}$ Selanjutnya Fitri Yuliana dalam tulisannya Redemptive-Historical Approach: Suatu Pendekatan Hermeneutis Injili yang Kristosentris menuliskan bahwa Alkitab merupakan teks yang memiliki pola sebagai cerita yang berkembang secara progressif hingga mencapai tujuan spesifik yang sudah ditetapkan Allah Tritunggal, tujuan spesifik itu adalah mahakarya ilahi dalam karya penebusan (redemption) yang disingkapkan dari masa ke masa yang telah nyata di dalam Yesus Kristus namun semakin sempurna pada konteks kedatangan-Nya kedua kali. ${ }^{28}$ Dengan demikian untuk membentuk sebuah formulasi sistem penafsiran dengan metode sejarah penebusan dengan memberikan berbagai analisis yang memusatkan konsep penafsiran kepada personalitas Kristus sesuai dengan apa yang dinyatakan Alkitab.

Prinsip Teologis metode Historical Redemptive Approach didasarkan pada Lukas 24:27 yang menyatakan bahwa: "Lalu Ia menjelaskan kepada mereka apa yang tertulis tentang Dia dalam seluruh Kitab Suci, mulai dari Kitab-Kitab Musa dan segala kitab nabinabi." Selanjutnya hal tersebut kembali dinyatakan dalam ayat 44 yang menyatakan "Ia berkata kepada mereka: "Inilah perkataan-Ku, yang telah kukatakan kepadamu ketika Aku masih bersama-sama dengan kamu, yakni

\footnotetext{
27 Geerhardus Vos, Biblical Theology: Old and New Testament (Carlisle: The Banner of Truth Trust, 1975), 23.

${ }^{28}$ Fitri Yuliana, "Redemptive-Historical Approach: Suatu Pendekatan Hermeneutis Injili Yang Kristosentris," Veritas : Jurnal Teologi Dan Pelayanan
}

bahwa harus digenapi semua yang ada tertulis tentang Aku dalam kitab Taurat Musa dan kitab nabi-nabi dan kitab Mazmur.” Mengenai metode tersebut Sidney Greidanus menggunakan istilah redemptive-historicalChrictocentris. Prinsip ini berarti seorang pengkhotbah harus mencermati bagaimana para penulis Perjanjian Baru menghubungkan tulisan-tulisan mereka dengan Perjanjian Lama. Dan itu berarti, panduan normatif dan terbaik untuk mengkhotbahkan Kristus dari Perjanjian Lama adalah Perjanjian Baru sendiri. Dengan demikian metode Historical redemptive Approach adalah sebuah metode penafsiran sejarah Alkitab dalam Perjanjian Baru berdasarkan di dalam konteks sejarah penebusan yang berpusat kepada Yesus Kristus.

Pendekatan sejarah penebusan (redemptivehistorical approach) artinya melihat sejarah Alkitab dalam konsep penebusan Yesus. Emauel Gerrit Singgih menuliskan beberapa metode dalam memahami Alkitab, pertama, model non/prakkritis, model ini dikontrol oleh sistem ajaran / teologi. Kedua, model kritis-historis, model ini berusaha melepaskan diri dari sistem ajaran / teologi tertentu, meskipun dalam kenyataan sulit berbuat seperti itu. Ketiga, model Kritis-Literer, membandingkan berbagai terjemahan. Keempat, model reader's response, model ini menekankan bukan hanya teks yang penting, melainkan pembaca juga sama pentingnya. Berdasarkan pengelompokan tersebut maka metode pendekatan sejarah penebusan sebagai model pendekatan non / prakritis. ${ }^{29}$ Meskipun demikian pendekatan yang prakritis bukan berarti mentiadakan sikap kritis terhadap teks. Para penafsir dapat menjadi kritis terhadap sebuah teks ketika telah

17, no. 2 (February 12, 2018): 147-61,

https://doi.org/10.36421/veritas.v17i2.313.

29 Emanuel Gerrit Singgih, Dua Konteks: Tafsir-Tafsir Perjanjian Lama Sebagai Respons Atas Perjalanan Reformasi Di Indonesia (Jakarta: BPK Gunung Mulia, 2009), X-Xii. 
memiliki sebuah kebakuan dalam pemikiran berdasarkan dari sebuah konsep doktrinal yang diyakini. Salah satunya doktrin sejarah penebusan, penulis selalu menjaga agar teks tidak dipahami berdasarkan asusmsi pribadi yang subyektif, karena penafsir telah dipusatkan pada perspektif sejarah penebusan. Herman N. Ridderbos menyatakan bahwa, "The redemptive -historical character of the New Testament authority." 30 Dengan demikian doktrin sejarah penebusan memberikan otoritas kejelasan dan terang Alkitab Perjanjian Baru di dalam karya Kristus.

Grant R. Osborne menuliskan bahwa walaupun manusia terbatas untuk menghasilkan sistem yang final dalam menafsirkan Kitab Suci namun manusia masih dapat melakukan sistematisasi teks Alkitab dengan merangkum menjadi satu kategori-kategori Alkitab yang beraneka ragam. ${ }^{31}$ Maka pada bagian ini akan memberikan sistematisasi yang menjadi kategori dalam membentuk pemikiran tentang pendekatan sejarah penebusan. Yuliana memberikan rangkuman bahwa ada tiga alat analisis pendekatan sejarah penebusan, yaitu pewahyuan (revelation), eskatologi (eschatology) dan tipologi (tipology). ${ }^{2}$ Ketiga alat analisis tersebut memberikan pemahaman bahwa untuk memahami sebuah teks Alkitab dengan pendekatan sejarah penebusan maka perlu melakukan kajian teks Alkitab berdasarkan analogi dan perkembangan sejarah pewahyuan dalam kisah Alkitab yang memiliki makna secara eskatologis. Selanjutnya Vern S. Poythress memberikan penjelasan bahwa kaitan antara pewahyuan, eskatologi dan tipologi, yaitu, pertama, Allah

\footnotetext{
$3^{\circ}$ Herman N Ridderbos, Biblical and Theological Studies, Redemptive History and The New Testament Scriptures (Philipsburg: Presbyterian and Reformed Publishing Company, n.d.), 49.

${ }^{31}$ Grant R Osborrne, Spiral Hermeneutika, ed. Stevy Tilaar, trans. Elifas Gani (Surabaya: Momentum, 2018), 10.
}

menyatakan sesuatu tidak dalam satu kali, tetapi berkelanjutan. Kedua, penyataan Allah dimasa yang akan datang mengiluminasi penyataan Allah sebelumnya. Ketiga, penyataan Allah selanjutnya merupakan penggenapan (fullfilment) dari pernyataan terdahulu sehingga Allah membukakan makan yang lebih dalam kepada umat-Nya. Keempat, firman Allah diperjelas oleh tindakan Allah dan tindakan Allah memperjelas firman-Nya. Kelima, segala tindakan dan firman Allah diarahkan dalam konteks tertentu, tahap tertentu sebagai bagian dari rangkaian keselamatan yang puncaknya pada karya Yesus serta penyempurnaannya terealisasi pada hadirnya langit dan bumi yang baru. 33 Dengan demikian skema rancang bangun pendekatan sejarah penebusan ialah dengan memahami sebuah teks Alkitab yang memiliki makna secara progresif pada setiap konteks dan makna tersebut bermakan kekal ketika dipahami pada konteks penyempurnaan (konsumasi).

Louis Berkhof menuliskan bahwa: "The new testament is a commentary on the Old. While the Old Testament contains but a shadowy representation of spiritual realities, the new testament presents them in the perfect light of fulness of time". Hal tersebut menunjukkan bahwa teks Perjanjian Lama diterangkan dan dijelaskan dalam Perjanjian Baru.34 Konsep ini menunjukkan bahwa narasi Perjanjian Lama tidak terutama menjadi contoh moral, tetapi sebagai penyataan Mesias yang akan datang. Narasi Perjanjian Lama berfungsi sebagai tipe dan bayangan yang menunjukkan sejarah dalam ketika Mesias dinyatakan dalam pribadi dan karya Yesus Kritus. Mengenai hal tersebut

${ }^{22}$ Yuliana, "Redemptive-Historical Approach: Suatu Pendekatan Hermeneutis Injili Yang Kristosentris." 33 Vern S Poythress, Reading the Word of God in the Presence of God: A Handbook for Biblical Interpretation (Wheaton: Crossway, 2016), 226. 34 Louis Berkhof, Principles of Biblical Interpretation (Grand Rapids, 1981), 137. 
Richard L. Pratt, Jr menuliskan bahwa penyataan Perjanjian Lama menunjuk pada kehadiran Yesus. Ia berkata, "Jikalau kamu percaya kepada Musa, tentu kamu akan percaya juga kepada-Ku sebab ia telah menulis tentang Aku" (Yoh. 5:46) dan "Abraham bapamu bersukacita bahwa ia akan melihat hari-Ku dan ia telah melihatnya dan ia bersukacita" (Yoh. 8:56). Perjanjian Baru ditegakkan di atas signifikansi kedatangan Kristus. Hal tersebut sesuai dengan pernyataan Paulus bahwa Ia memberitakan Kristus yang disalibkan (1Kor. 1:23). Dengan demikian berdasarkan pernyataan tersebut Kristus adalah fokus seluruh sentral Alkitab. 35

Richard Lints menuliskan agar dapat mengembangkan tiga analisis dalam memahami teks melalui pendekatan sejarah penebusan, maka perlu mengerti horison dalam hermeneutika sejarah penebusan. Lints menuliskan ada tiga horison yang perlu dipahami, yaitu: horizon teks (the textual horizon), horizon zaman (the ephocal horizon) dan horizon kanon (the canonical horizon). ${ }^{36}$ Horizon teks merupakan wilayah penafsiran yang menghadapkan seorang penafsir terhadap keragaman teks (variant teks), simbol, perumpamaan, genre, gramatika, dan konteks sejarah perlu dikaji untuk mendapatkan makna. Selanjutnya horizon zaman menuntut penafsir memahami konsep pewahyuan dan realiasai penebusan secara progresif di dalam Alkitab seperti yang dituliskan oleh VanGemerem tentang dua belas periode sejarah penebusan.37 Lints menuliskan bahwa penyataan Allah yang progresif memperlihatkan sisi personalitas Allah yang unik dan berbeda pada setiap masa, sehingga

\footnotetext{
35 Richard L Pratt, He Gave Us Stories (Surabaya:

Momentum, 2005), 379.

${ }^{36}$ Richard Lints, The Fabric of Theology: A

Prolegomenon to Evangelical Theology (Grand Rapids:

Eerdmans, 1993), 293-309.
}

menyatukan ide besar setiap zaman di mana Allah menyatakan diri-Nya merupakan tugas utama seorang penafsir agar teks yang ditafsirkan mengikuti benang merah horizon zaman, dalam prinsip teologis ini sejarah penebusan merupakan kerangka besar dalam horizon setiap zaman, meskipun Allah menyatakan dengan cara yang unik kepada umat-Nya dalam zaman yang berbeda. Penafsir juga dituntut memahami horizon kanon yaitu melihat teks-teks Alkitab yang ada sebagai sebuah kesatuan antara janji (promise) dan penggenapan (fullfilment), selain itu penafsir juga didorong agar memahami Alkitab dalam konteks komunitas Kristen mula-mula, sehingga setiap teks akan dipahami ditulis oleh manusia yang diinspirasikan oleh Roh Kudus untuk menjawab konteks yang hadir dalam komunitas orang percaya saat itu, maka keberadaan teks dan makna teks akan memiliki kekhususan secara konteks namun bernilai universal secara prinsip. Dengan demikian untuk mendapatkan makna teks yang universal dan kekal, maka sebuah teks perlu dipahami relevansinya pada konteks puncak sejarah penebusan, yang secara eskatologis pada masa penyempurnaan (konsumasi). Pemahaman teks yang didapatkan dari setiap konteks Alkitab yang ada perlu ditinjau dalam benang merah sejarah penebusan, sehingga makna dan relevansi teks tidak hanya berlaku pada masa lalu, namun juga masa kini dan masa yang akan datang.

Yi Wang dalam tulisannya tentang 'redemptivehistorical hermeneutics and application' memberikan penjelasan tentang penerapan metode tersebut secara khusus pada teks-teks yang memberikan muatan historis, nubuatan,

\footnotetext{
37 VanGemeren, Progress Penebusan: Kisah Keselamatan dari Penciptaan sampai Yerusalem Baru, 20.
} 
tipologi, etika, sastra dan hukum. Wang menegaskan bahwa seluruh teks Alkitab wajib dibaca dalam kerangka sejarah penebusan, sehingga menurut pendapatnya ada beberapa metode yang perlu diterapkan saat menafsirkan teks Alkitab, pertama, memperhatikan konteks sejarah teks dalam konteks penebusan. Kedua, pribadi dan karya Kristus sebagai pendekatan terhadap teks-teks Alkitab yang memiliki unsur nubuatan, tipologi dan bahasa hikmat. Ketiga, menyimpulkan sebuah aplikasi dari hukum Taurat berdasarkan dari terang Injil.38 Dengan demikian penerapan metode pendekatan sejarah penebusan sangat efektif terhadap teks-teks Kitab sejarah, Taurat, Nubuat dan Sastra. Osborne menuliskan bahwa pendekatan sejarah penebusan termasuk dalam kategori metode sintesis, terpusat dan menyatukan, ia menuliskan ada enam kriteria untuk dapat menerapkan metode sejarah penebusan, pertama, tema harus menyatakan natur/karakter keallahan, kedua, tematemanya harus memberikan penjelasan tentang umat Allah dalam relasinya dengan Allah, dunia dan sesama. Ketiga, konsepkonsepnya harus mencakup dunia umat manusia sebagai objek dari kasih yang menebus dari Allah. Keempat, temanya menjelaskan hubungan dialektis kedua perjanjian. Kelima, tema-temanya berisi dan merangkum penekanan individual dari tiap bagian Kitab Suci. Keenam, tema-tema yang individual disatukan dalam satu tema tunggal seperti tema penebusan.39 Meskipun demikian pendekatan sejarah penebusan yang termasuk kategori metode terpusat atau Kristologis tetap perlu menjaga agar tidak mengaburkan maknamakna individual, ia menuliskan sebuah masukan agar jangan sampai hanya demi

${ }^{8}$ Yi Wang, "Redemptive-Historical Hermeneutics and Applications" (Westminster Seminary California, 2015), http://www.reformedbeginner.net/wp- menemukan sebuah 'relevansi' mengaburkan dan menghilangkan kekhasan sebuah teks yang telah memiliki sejarah kanon tersendiri baik Perjanjian Lama dan Perjanjian Baru.40 Dengan demikian seorang penafsir yang menerapkan pendekatan sejarah penebusan perlu berhatihati agar tetap menjaga perlunya memahami teks pada konteks penulis, setelah menemukan makna secara individual maka makna tersebut baru dapat dilihat dalam konteks universalitas seluruh teks.

\section{Kesimpulan}

Pendekatan sejarah penebusan adalah prinsip penafsiran Alkitab yang didasarkan pada konsep doktrinal tentang karya Allah Tritunggal. Pendekatan sejarah penebusan memandang sebuah teks Alkitab dalam perspektif karya penebusan yang telah direalisasikan oleh Yesus Kristus dan akan digenapi dalam konteks penyempurnaan di langit dan bumi yang baru. Pendekatan melalui sejarah penebusan menjadi sebuah antisipasi dalam konteks hermeneutika, sehingga menghindari adanya pemahaman teks Alkitab secara subyektif dan lokal. Melalui benang merah sejarah penebusan mendorong para penafsir agar memiliki ketekunan dalam meninjau sebuah teks secara progresif dalam setiap zaman di Alkitab dan melakukan kajian secara mendalam untuk melihat relevansi teks dalam konteks kekekalan, dengan demikian penafsir tidak bisa sembarangan memaknai naskah Alkitab hanya untuk kepentingan pribadi atau kelompok tertentu, namun Alkitab ditafsirkan hanya dan untuk menerangkan realisasi karya penebusan yang berpusat kepada Yesus Kristus. Pendekatan sejarah penebusan

content/uploads/2017/03/Redemptive-historicalHermeneutics-and-Application_PT500_paper.pdf. 39 Osborrne, Spiral Hermeneutika, 447.

$4^{\circ}$ Osborrne, 444. 
juga tidak melepaskan kajian-kajian teks secara kontekstual, namun kajian tersebut justru semakin dikuatkan dengan melihat makna teks pada konteksnya dalam kaitan dengan sejarah penebusan. Secara khusus pendekatan sejarah penebusan juga menolong para penafsir Alkitab agar tetap menjaga garis lurus konsep Alkitab, di tengah kondisi tuntutan agar seorang penafsir mampu menyajikan pemahaman sebuah teks Alkitab yang relevan, cepat dan tepat. Sehingga pendekatan sejarah penebusan merupakan terobosan penting agar penafsiran dapat menjawab sikap umat Kristen pada konteks postmodern yang mulai meniadakan adanya sebuah pusat pemikiran (sentralitas) Alkitab. Dengan demikian sangat disarankan agar para penafsir dan para pembaca Alkitab mengetahui secara doktrinal tentang sejarah penebusan dan memahami bagaiman dokrin sejarah penebusan juga dapat diimplementasikan dalam penafsiran Alkitab, dengan tetap menemukan makna individual dari setiap penulis Kitab.

\section{Kontribusi Penelitian}

Penelitian ini memperkuat pemahaman doktrinal tentang sejarah penebusan (kontribusi teologis) dan memelihara konsistensi dalam pemberitaan karya Kristus dalam setiap pembacaan dan penafsiran Alkitab untuk tujuan misiologis. Aplikasinya dapat dipergunakan untuk pengembangan kurikulum dalam teologi sistematika dan ilmu hermenetika.

\section{Rekomendasi Penelitian}

Perlunya penelitian rumusan konsep eskatologis tentang puncak sejarah penebusan pada masa penyempurnaan (konsumasi) sebagai data untuk menegaskan relevansi teks Alkitab, pengembangan tulisan Willem VanGemeren tentang sejarah penebusan dan konsep kehidupan di bumi dan langit yang baru, karena perbedaan konsep eskatologis akan memberikan pengaruh signifikan dalam menerapkan metode sejarah penebusan.

\section{Referensi}

Asali, Budi. "10 Hukum Tuhan: Hukum Kedelapan." Golgotha Ministry. Accessed February 27, 2021. http://www.golgothaministry.org/artikel/pengajar an_10hukumo8.htm.

Berkhof, Louis. Principles of Biblical Interpretation. Grand Rapids, 1981.

Chia, Philip Suciadi, and Juanda Juanda. "Dispensasionalisme Sebagai Metode Dalam Memahami Alkitab." Jurnal Teologi \& Pelayanan KERUSSO 5, no. 1 (2020): 20-37.

---. "Penafsiran Amilenialisme \& Teologi Kovenan Dalam Memahami Alkitab.” Journal KERUSSO 5, no. 2 (February 27, 2020): 1-23. https://doi.org/10.33856/kerusso.v5i2.125.

Grenz, Stenly J. A Primer On Postmodenism. Yogyakarta: ANDI, 2001.

Horton, Michael. Covenant and Eschatology: The Divine Drama. Louisville: Wesrminster John Knox, 2002.

Hyun, Yung Hoon. Redemptive-Historical Hermeneutics and Homiletics: Debates in Holland, America, and Korea from 1930 to 2012. Wipf and Stock Publishers, 2015.

Johnson, Philip C. "Keluaran." In The Wyclife Bible Commentary, 1st ed., 1:204. Malang: Gandum Mas, 2011.

Kristanto, Billy, ed. "Metode Bertheologi Reformed." In Aspek-Aspek Dalam Pemikiran John Calvin, 2021. Surabaya: Momentum, 2012.

Kusnandar, Christie. "Sepuluh Perintah Tuhan Bagian Kedua: Kasih Terhadap Manusia Dalam Tinjauan Etika Kristen.” Jurnal Ilmiah Methonomi 3, no. 2 (2017): 73-82.

Lumintang, Ramly B. Bahaya Postmodernism Dan Peranan Kredo Reformed. Batu: PPII, 2010.

Meeter, Henry. The Basic Idea of Calvinism. Vol. 6. Grand Rapids: Baker Academic, 1990.

Ong, Thuan, and Imanuel Zai. "Memahami Konsep Penebusan Dalam Hukum Taurat Dan Penggenapannya Dalam Diri Yesus Kristus.” Jurnal Teologi Pondok Daud 6, no. 1 (2020): 1-7.

Osborrne, Grant R. Spiral Hermeneutika. Edited by Stevy Tilaar. Translated by Elifas Gani. Surabaya: Momentum, 2018. 
Poythress, Vern S. Reading the Word of God in the Presence of God: A Handbook for Biblical Interpretation. Wheaton: Crossway, 2016.

Pratt, Richard L. He Gave Us Stories. Surabaya: Momentum, 2005.

Ridderbos, Herman N. Biblical and Theological Studies, Redemptive History and The New Testament Scriptures. Philipsburg: Presbyterian and Reformed Publishing Company, n.d. 49.

Singgih, Emanuel Gerrit. Dua Konteks: TafsirTafsir Perjanjian Lama Sebagai Respons Atas Perjalanan Reformasi Di Indonesia. Jakarta: BPK Gunung Mulia, 2009. X-Xii.

Sumakul, H W B. Postmodernitas: Memaknai Masyarakat Plural Abad Ke - 21. Jakarta: BPK Gunung Mulia, 2012.

Supriadi, Made Nopen. "Tinjauan Teologis Terhadap Postmodernisme Dan Implikasinya Bagi Iman Kristen.” Manna Rafflesia, 2020. https://doi.org/10.38091/man_raf.v6i2.115.

Supriadi, Made Nopen, Iman Kristina Halawa, and Regueli Daeli. "Tinjauan Teologis Realisasi Perintah Jangan Mencuri Dalam Keluaran 20: 15 Berdasarkan Perspektif Sejarah Penebusan." JURNAL LUXNOS 6, no. 2 (2020): 213-34. https://doi.org/https://doi.org/10.47304/jl.v6i2.4

3 .

Tunliu, Misray. "Eksistensi Kanon Alkitab Dan Relevansinya Di Era Globalisasi.” PRUDENTIA: Jurnal Teologi Dan Pendidikan Kristiani 1, no. 2 (2018): 148-63.

VanGemeren, Willem. Progress Penebusan: Kisah Keselamatan Dari Penciptaan Sampai Yerusalem Baru. Surabaya: Momentum, 2016.

Vos, Geerhardus. Biblical Theology: Old and New Testament. Carlisle: The Banner of Truth Trust, 1975.

Wang, Yi. "Redemptive-Historical Hermeneutics and Applications." Westminster Seminary California, 2015.

http://www.reformedbeginner.net/wpcontent/uploads/2017/o3/Redemptive-historicalHermeneutics-and-Application_PT500_paper.pdf.

Wauran, Queency Christie. "Kajian Biblika Kecemburuan Allah Terhadap Penyembahan Berhala Berdasarkan Keluaran 20:4-6.” Jurnal Jaffray 13, no. 2 (February 13, 2015): 249. https://doi.org/http://dx.doi.org/10.25278/jj71.v1 3i2.180.

Yuliana, Fitri. "Redemptive-Historical Approach: Suatu Pendekatan Hermeneutis Injili Yang Kristosentris." Veritas : Jurnal Teologi Dan
Pelayanan 17, no. 2 (February 12, 2018): 147-61. https://doi.org/10.36421/veritas.v17i2.313.

Zaluchu, Sonny Eli. Biblical Theology. Semarang: Sina'i Publisher, 2019.

--_. "Metode Penelitian Di Dalam Manuskrip Jurnal Ilmiah Keagamaan.” Jurnal Teologi Berita Hidup 3, no. 2 (March 25, 2021): 249-66. https://doi.org/10.38189/jtbh.v3i2.93.

- - . "Persoalan Corpus Delicti Dalam Teologi Kristen Tentang Persidangan Ilahi." KURIOS (Jurnal Teologi Dan Pendidikan Agama Kristen) 6, no. 2 (2020): 214-26. https://doi.org/https://doi.org/10.30995/kur.v6i2. 172. 